\title{
Competition in the global arms trade markets and its consequences
}

\author{
Irina Tulyakova ${ }^{1}$, Victor Dengov ${ }^{1, *}$ and Elena Gregova $^{2}$ \\ ${ }^{1}$ Saint Petersburg State University, Faculty of Economics, Department of Economics \& Economic \\ Policy, University embankment 7-9, 199034, St Petersburg, Russia \\ ${ }^{2}$ University of Zilina, Faculty of Operation and Economics of Transport and Communications, \\ Department of Economics, Univerzitna 1, 01026 Zilina, Slovakia
}

\begin{abstract}
Research background: The global arms markets are constantly fiercely competitive. Over the past period, new important trends have emerged in these markets, and the role of some countries is changing. This requires analytical reflection in order to assess the prospects for Russian arms exports. The authors have repeatedly addressed the topic of Russian arms exports and the place of Russia in the global arms and military equipment trade markets.

Purpose of the article: The main purpose of the study is to analyze the current state of the global AME markets in individual segments, compare the positions of its main participants and assess the prospects for Russia's presence in these markets in the future.

Methods: Generalizations of the research are based on the processing and systematization of data obtained from available information sources. By analyzing the statistics, the authors were able to deduce the trends of the current moment and determine the prospects.

Findings \& Value added: Analysis of the positions of individual "players" in these markets and the trends identified allowed the authors to make an educated guess about how events might develop in the future. Despite all the changes taking place in the global arms and military equipment markets, Russia has good prospects for maintaining and strengthening its positions in certain areas.
\end{abstract}

Keywords: max global arms markets; world arms exports and imports; military spending and arms trade

JEL Classification: F14; L64; O57

\section{Introduction}

The global market of weapons and military equipment (WME) is an important component not only of foreign policy, but also world trade. Leading countries of this market largely

* Corresponding author: v.dengov@spbu.ru 
determine the situation around the world (Blum, 2019; Tulyakova, 2016; Tulyakova et al., 2017; Tulyakova et al., 2019). Almost all countries need weapons, but not all are capable of producing the weapons they need.

The overwhelming majority of the WME supply on the world market comes from three "players"- USA, Russia and the EU. They have long formed multi-sectoral military-industrial complexes (MIC), spend huge sums on military spending, have long and successfully produced the entire range of military equipment, a significant part of which is supplied to the world market. Their positions on the world market, the share of the total volume of arms sales, the circle of buyers of their products is sufficient stable (Dengov et al., 2021; Gregova et al., 2021). Weapons are long-term and expensive products. Its operation is calculated for many decades.

At the same time, the trend of the emergence of new players is more and more clearly visible in the global WME export market. Someone, like China, has already seriously stated its claims as a major exporter of WME (Bitzinger, 2016; Wang et al., 2019), someone has great potential to become such in the very near future (South Korea, Saudi Arabia, United Arab Emirates, India, Japan).

The transformation from an importer of WME to its exporter was initially undoubtedly associated with a long-term the buildup of military spending. Some countries claiming the role of regional and even world leaders started by purchasing military products from their traditional partners. For example, for several decades of the XX and even the XXI century, China and India were the largest consumers of Russian weapons (Dengov et al., 2018; Tulyakova \& Dengov, 2018). Having created their own diversified military production, they are now part of their own production WME began to actively supply other countries, creating competition for the "leading three" in the markets third countries (including Africa, Latin America and the Middle East). A similar picture can be observed in relation to a number of other countries. South Korea, Saudi Arabia and United Arab Emirates are still the largest WME importer but is gradually creating its large and technologically advanced defense companies.

\section{Methodology, databases and analytical sources of research}

WME global market statistics can be based on several databases provided by the world's major defense and security think tanks (Skons \& Dunne, 2008).

In the annual global ranking of think tanks "2019 Global Go To Think Tank Index Report" in the "Top Defense and National Security" section (2019), the first place is occupied by the International Institute for Strategic Studies (IISS) (UK), which annually publishes the Military Balance bulletin, the annual assessment of military capabilities and defense economics of 171 countries worldwide. However, only some of the information from the IISS bulletins appears in the public domain. However, only some of the information from the IISS bulletins appears in the public domain. In the general list of 110 rated centers, most places are occupied by American and European centers, although there are also Asian ones. Russia is represented by 5 centers: Institute of World Economy and International Relations (38th place); Institute for the U.S. and Canadian Studies (40th); Council on Foreign and Defence Policy (58th); Moscow State Institute of International Relations (69th); Russian International Affairs Council (107th).

In addition to these Russian centers, the necessary information can be found on the websites of the Centre for Analysis of World Arms Trade (CAWAT) and Interfax Group. The CAWAT methodology offers independently calculated statistics based on the price parameters of contracts quoted in current US dollars at the time of the transaction. There is also an opportunity to trace the physical volumes of deliveries to the market. To do this, you can use the statistics provided by the United Nations Register of Conventional Arms. The Register was created by a United Nations resolution in 1991 and is a global instrument for 
the transparency of arms transfers between countries. Since 1993, Russia has been annually providing information on the export/import of weapons. The big disadvantage of this method of market research is that the Register is based on information voluntarily provided by each country, and this is not always followed by everyone.

With all the abundance of information sources, the complexity of the study of arms markets lies in the fact that all of them, as a rule, use their own differing methods of information assessment. To estimate the value of WME sales, you need to have price data that is not always available (Akbas-Yesilyurt \& Yesilyur, 2020). At the same time, the use of different mechanisms for calculating and determining prices for different types of WME leads to significant discrepancies. Therefore, in one study it is necessary to mainly use data from only one agency. For international comparisons, we have chosen the databases of the Stockholm International Peace Research Institute (SIPRI) (CAWAT, 2016). This allows, without having $100 \%$ reliable figures, at least to observe the main trends. SIPRI is a recognized world authority in this area of research, although in this ranking it only takes the 24th position. The statistics provided by this agency are used by many researchers, are completely open, but have their own specific assessment methodology (Fleurant and Tian, 2018).

When referring to statistics from SIPRI, it should be borne in mind that the approach of the so-called "Trend Indicator Values" (TIV's) is used in assessing the cases of arms transfers. The peculiarity of this approach is that analogs of military products are assigned the same cost regardless of the country manufacturer. This unambiguously distorts the assessment of the financial return on arms sales for individual countries, but at the same time more adequately reflects the physical volume of products sold. For example, similar weapons made in China and the United States have different costs; but if an equal number of weapons are supplied, then these volumes are assessed by SIPRI as the same (Liu et al., 2014). Thus, the SIPRI data lead to overestimation of the indicators of countries supplying cheaper types of weapons. This is why the export shares of Russia and China are often overstated compared to the shares of other exporting countries such as the United States, France and UK.

Statistical methods and methods of system analysis are used in this article as analysis tools.

\section{Results}

To assess the state of the global WME market at the moment, let's turn to the data in the table 1. It presents the 10 largest exporters and importers of WME each, indicating the share of the respective country in the global market.

Table 1. TOP-10 largest exporters and importers of the WME market for the period 2015-2019 in\% of the total volume of exports / imports

\begin{tabular}{|l|c|l|c|}
\hline \multicolumn{2}{|c|}{ Exporters } & \multicolumn{2}{c|}{ Importers } \\
\hline \multicolumn{1}{|c|}{ country } & share & \multicolumn{1}{c|}{ country } & share \\
\hline USA & 36 & Saudi Arabia & 12 \\
\hline Russia & 21 & India & 9,2 \\
\hline France & 7,9 & Egypt & 5,8 \\
\hline Germany & 5,8 & Australia & 4,9 \\
\hline China & 5,5 & China & 4,3 \\
\hline UK & 3,7 & Algeria & 4,2 \\
\hline Spain & 3,1 & South Korea & 3,4 \\
\hline Israel & 3,0 & UAE & 3,4 \\
\hline Italy & 2,1 & Iraq & 3,4 \\
\hline South Korea & 2,1 & Qatar & 3,4 \\
\hline
\end{tabular}

Source: compiled by the authors according to the SIPRI Yearbook 2020 
As can be seen from the table, the two leading WME exporters - the United States and Russia - account for more than half (57\%) of all world arms exports, and the 4 largest exporters (including France and Germany) account for almost $71 \%$. But let's pay attention that the 5 th place in the list of the largest exporters is confidently taken by China $(5,5 \%)$ which is also in the fifth place, but already in the list of the largest importers. A similar situation is with South Korea, which was among the ten largest exporters, but at the same time is in 7th place in the list of importers. The rest of the WME exporters from the top ten in the list of TOP-10 importers are not marked.

So, the United States has been and remains the largest player in the market, and Russia is confidently in second place (GLOBAL FIREPOWER, 2021). Now let's look at the volumes of exports from these two countries, the circle of the main recipients of their weapons and the types of exported products. Figures are SIPRI Trend Indicator Values (TIVs) expressed in millions USD.

Table 2. Arms and military equipment exports from US and Russia in 2000-2020 (USD million)

\begin{tabular}{|l|c|c|c|c|c|c|c|c|c|c|c|c|}
\hline & $\mathbf{2 0 0 0}$ & $\mathbf{2 0 0 2}$ & $\mathbf{2 0 0 4}$ & $\mathbf{2 0 0 6}$ & $\mathbf{2 0 0 8}$ & $\mathbf{2 0 1 0}$ & $\mathbf{2 0 1 2}$ & $\mathbf{2 0 1 4}$ & $\mathbf{2 0 1 6}$ & $\mathbf{2 0 1 8}$ & $\mathbf{2 0 2 0}$ & $\mathbf{2 0 0 0 - 2 0 2 0}$ \\
\hline USA & 7571 & 4891 & 6847 & 7545 & 6807 & 8062 & 9056 & 9604 & 9868 & 9895 & 9372 & 171522 \\
\hline Russia & 4486 & 5730 & 6252 & 5126 & 6175 & 6214 & 8180 & 5469 & 6790 & 6753 & 3203 & 124331 \\
\hline
\end{tabular}

Source: compiled by the authors according to the SIPRI Yearbook 2020

As can be seen from the Table 2, throughout the twenty-year period, the United States has practically constantly increased the volume of WME exports. The volumes of export deliveries from Russia do not show an obvious upward or downward trend, fluctuating over the years.

Table 3. Largest partners and volumes of arms and military equipment exports from the USA and Russia in 2000-2020 (USD million)

\begin{tabular}{|l|r|l|r|}
\hline \multicolumn{2}{|c|}{ USA } & \multicolumn{2}{c|}{ Russia } \\
\hline Partner Country & Export Volume & Partner Country & Export Volume \\
\hline Saudi Arabia (SA) & 19142 & India & 35818 \\
\hline South Korea (SK) & 15450 & China & 30816 \\
\hline Australia & 11752 & Algeria & 12070 \\
\hline UAE & 11419 & Viet Nam & 6479 \\
\hline Japan & 9042 & Egypt & 4769 \\
\hline Israel & 8374 & Venezuela & 3850 \\
\hline United Kingdom & 8101 & Iraq & 2386 \\
\hline Others & 88242 & Others & 28143 \\
\hline Total & 171522 & Total & 124331 \\
\hline
\end{tabular}

Source: compiled by the authors according to the SIPRI Yearbook 2020

As can be seen from Table 3, the largest partners of the United States are countries with high solvency. Many of them have their own highly developed and high-tech production facilities WME. The list of Russia's partners shows that their level of income is significantly lower (except for China). Moreover, Russia's partners cannot be a source of new developments in the field of defense production for it. Circle of importing countries the US has significantly more, than Russia. Moreover, the largest flow of American weapons goes to SA - but this is only about $11 \%$. The complexity of Russia's position on the WME markets is that the two major partners in terms of export volumes account for more than $50 \%$ of supplies (India - 29\%, China - 25\%). In the event of the possible loss of these partners, Russia's exports will be greatly reduced.

The data from Table 4 show that both the United States and Russia produce and export all known types of military products. The predominant products in US exports are aircraft, missiles and armored vehicles, in Russian exports - the same types plus warships. At the same 
time, the United States is also a major importer of weapons and military equipment. During the same period, the United States imported weapons and military equipment in the amount of $\$ 14596$ million (about $9 \%$ of the total exports). The largest suppliers of weapons and military equipment to the United States are UK, Canada, Germany and Switzerland.

Table 4. Exports WME by types from the USA and Russia in 2000-2020 (USD million)

\begin{tabular}{|l|r|r|}
\hline \multicolumn{1}{|c|}{ Type WME } & US export volume & Russian export volume \\
\hline Aircraft & 99591 & 61516 \\
\hline Air defence systems & 5850 & 10022 \\
\hline Armoured vehicles & 17570 & 11395 \\
\hline Artillery & 1007 & 442 \\
\hline Engines & 6636 & 6689 \\
\hline Missiles & 25984 & 18766 \\
\hline Naval weapons & 2099 & 482 \\
\hline Satellites & - & 150 \\
\hline Sensors & 7939 & 1821 \\
\hline Ships & 4241 & 12521 \\
\hline Other & 604 & 528 \\
\hline Total & 171522 & 124331 \\
\hline
\end{tabular}

Source: compiled by the authors according to the SIPRI Yearbook 2020

Russia practically never bought anything from other manufacturers. SIPRI estimates imports to Russia over a 20-year period at $\$ 1007$ million, with Ukraine being the main supplier of military products to Russia ( $\$ 850$ million), mainly because after the collapse of the USSR, a significant part of the still Soviet defense industries remained there.

Another difference between the USA and Russia is that, as the largest supplier of weapons and military equipment to the world market, the USA spends most of its military spending on equipping its own army. In recent years, the United States has been selling weapons for about 9 billion dollars abroad, at the level of military expenditures of about $\$ 700$ billion. The situation is different for Russia, whose military expenditures are several times less and amount to about $\$ 60$ billion. At the same time, annual exports are equal to $\$ 5-6$ billion.

The second group of exporters of weapons and military equipment should include France and Germany. They lag significantly behind the market leaders - the USA and Russia, but at the same time they have been holding their high positions in the export market for many decades.

Table 5. Arms and military equipment exports from France and Germany in 2000-2020 (USD million)

\begin{tabular}{|l|c|c|c|c|c|c|c|c|c|c|c|c|}
\hline & $\mathbf{2 0 0 0}$ & $\mathbf{2 0 0 2}$ & $\mathbf{2 0 0 4}$ & $\mathbf{2 0 0 6}$ & $\mathbf{2 0 0 8}$ & $\mathbf{2 0 1 0}$ & $\mathbf{2 0 1 2}$ & $\mathbf{2 0 1 4}$ & $\mathbf{2 0 1 6}$ & $\mathbf{2 0 1 8}$ & $\mathbf{2 0 2 0}$ & $\mathbf{2 0 0 0 - 2 0 2 0}$ \\
\hline France & 1079 & 1428 & 2301 & 1664 & 1978 & 870 & 1029 & 1656 & 2088 & 1784 & 1995 & 37669 \\
\hline Germany & 1615 & 912 & 1105 & 2707 & 2368 & 2666 & 750 & 1790 & 2506 & 1070 & 1232 & 35865 \\
\hline
\end{tabular}

Source: compiled by the authors according to the SIPRI Yearbook 2020

As can be seen from the Table 5, over the same period, it is difficult to detect any clear trend in the export of weapons and military equipment from France and Germany. Their sales over the years fluctuate somewhere in the region from 0.8 to 2.7 billion dollars, which may indicate a certain instability of the order portfolio and the related unevenness of sales. The smaller the total order book, the greater the spread of export sales over the years will be, and vice versa.

If we looked at the entire list of arms and military equipment importers from France and Germany (and not only the main ones, see Table 6), we would see that both countries are present in the same markets, i.e., compete with each other. At the same time, like the situation with the United States, supplies from France and Germany are diversified so that even the largest 
importing countries have a relatively small share (in the case of France, this is $14 \%$ of supplies to the UAE and in the case of Germany, $11 \%$ of supplies to South Korea).

Table 6. Largest partners and export volumes of weapons and military equipment from France and Germany for 2000-2020 (million dollars)

\begin{tabular}{|l|r|l|r|}
\hline \multicolumn{2}{|c|}{ France } & \multicolumn{2}{c|}{ Germany } \\
\hline Partner Country & \multicolumn{1}{|c|}{ Export Volume } & Partner Country & Export Volume \\
\hline UAE & 5236 & South Korea & 3967 \\
\hline China & 3279 & Greece & 3381 \\
\hline India & 3168 & Turkey & 2455 \\
\hline Egypt & 3024 & South Africa & 1831 \\
\hline Saudi Arabia & 2501 & United States & 1784 \\
\hline Singapore & 2256 & Australia & 1763 \\
\hline Others & 18205 & Others & 20684 \\
\hline Total & 37669 & Total & 35865 \\
\hline
\end{tabular}

Source: compiled by the authors according to the SIPRI Yearbook 2020

From the data in the table 7, one can see a large specialization of France in the sale of aircraft, while Germany sells more naval equipment and ships. At the same time, the total range of types of weapons for both countries are almost complete.

Table 7. Exports WME by types from France and Germany in 2000-2020 (USD million)

\begin{tabular}{|l|r|r|}
\hline \multicolumn{1}{|c|}{ Type WME } & France export volume & Germany export volume \\
\hline Aircraft & 14708 & 3874 \\
\hline Air defence systems & 1451 & 743 \\
\hline Armoured vehicles & 1159 & 7674 \\
\hline Artillery & 362 & 1070 \\
\hline Engines & 1818 & 2965 \\
\hline Missiles & 5570 & 2383 \\
\hline Naval weapons & 50 & 15951 \\
\hline Sensors & 3665 & 1123 \\
\hline Ships & 8504 & 15951 \\
\hline Other & 133 & 82 \\
\hline Total & 37669 & 35865 \\
\hline
\end{tabular}

Source: compiled by the authors according to the SIPRI Yearbook 2020

The list of exporters and importers includes two countries that are simultaneously included in both groups (see Table 1). These are the China and South Korea.

For many years, the China was a major importer, and is increasingly showing itself as an exporter and competitor, including Russia (see Table 8).

Table 8. Arms and military equipment exports from China and South Korea in 2000-2020 (USD million)

\begin{tabular}{|l|c|c|c|c|c|c|c|c|c|c|c|c|}
\hline & $\mathbf{2 0 0 0}$ & $\mathbf{2 0 0 2}$ & $\mathbf{2 0 0 4}$ & $\mathbf{2 0 0 6}$ & $\mathbf{2 0 0 8}$ & $\mathbf{2 0 1 0}$ & $\mathbf{2 0 1 2}$ & $\mathbf{2 0 1 4}$ & $\mathbf{2 0 1 6}$ & $\mathbf{2 0 1 8}$ & $\mathbf{2 0 2 0}$ & $\mathbf{2 0 0 0 - 2 0 2 0}$ \\
\hline China & 295 & 523 & 411 & 664 & 651 & 1475 & 1526 & 1212 & 2410 & 1169 & 760 & 22268 \\
\hline South Korea & 10 & - & 73 & 158 & 109 & 198 & 224 & 207 & 480 & 1056 & 827 & 6507 \\
\hline
\end{tabular}

Source: compiled by the authors according to the SIPRI Yearbook 2020

If you do not take into account the last two years, it can be noted that both countries have rapidly increased their exports, although the total volume of Chinese exports is about 3.5 times more than South Korean.

China's partners, just like Russia, are not very rich countries (see Table 9). Moreover, almost $40 \%$ of all exports go to Pakistan. In addition to Pakistan, the list of China's partners includes the same countries as consumers of Russian exports. The list of partners of the South 
Korea indicates that the country is not, for the most part, a competitor to the China, but it has overlapping markets with Russia (India).

Table 9. Largest partners and export volumes of weapons and military equipment from China and South Korea for 2000-2020 (million dollars)

\begin{tabular}{|l|r|l|r|}
\hline \multicolumn{2}{|c|}{ China } & \multicolumn{2}{c|}{ South Korea } \\
\hline Partner Country & \multicolumn{1}{|c|}{ Export Volume } & Partner Country & Export Volume \\
\hline Pakistan & 8777 & Turkey & 1412 \\
\hline Bangladesh & 2886 & Indonesia & 1219 \\
\hline Myanmar & 1699 & United Kingdom & 532 \\
\hline Algeria & 1024 & Philippines & 493 \\
\hline Iran & 781 & Thailand & 434 \\
\hline Venezuela & 629 & India & 432 \\
\hline Others & 6472 & Others & 1985 \\
\hline Total & 22268 & Total & 6507 \\
\hline
\end{tabular}

Source: compiled by the authors according to the SIPRI Yearbook 2020

In 20 years China has acquired the necessary competencies in the development and production of almost all types of weapons and military equipment. Despite the small export volumes compared to the China and not such a large range of weapons and military equipment, the South Korea has succeeded in the production and sale of some of them, in particular in military shipbuilding (see Table 10).

Table 10. Exports WME by types from China and South Korea in 2000-2020 (USD million)

\begin{tabular}{|l|r|r|}
\hline \multicolumn{1}{|c|}{ Type WME } & China export volume & South Korea export volume \\
\hline Aircraft & 7212 & 1340 \\
\hline Air defence systems & 1238 & 0 \\
\hline Armoured vehicles & 4267 & 73 \\
\hline Artillery & 740 & 2004 \\
\hline Naval weapons & 56 & - \\
\hline Sensors & 930 & - \\
\hline Missiles & 3297 & 46 \\
\hline Ships & 4528 & 3043 \\
\hline Other & 1 & - \\
\hline Total & 22268 & 6507 \\
\hline
\end{tabular}

Source: compiled by the authors according to the SIPRI Yearbook 2020

The countries that still have small export volumes, but with good prospects for the future, include India, SA and UAE.

India has long sought to establish its own production, paying great attention not so much to the purchase of weapons as to the purchase of licenses for its production. During the Soviet period, India purchased military products mainly from the USSR. In the post-Soviet period, competition has intensified, due to the parish of the United States, France and Israel. Currently, Indian military production has grown so much that it has allowed it to begin, albeit in small volumes, to export its weapons (see Table 11).

The desire to become independent from the import of weapons and military equipment, the high demand for weapons and financial capabilities lead to the creation of new national defense companies, in particular, in the Middle East (UAE and SA). 
Table 11. Exports AME from India, SA and UAE for 2000-2020 (USD million)

\begin{tabular}{|l|c|c|c|c|c|c|c|c|c|c|c|c|}
\hline & $\mathbf{2 0 0 0}$ & $\mathbf{2 0 0 2}$ & $\mathbf{2 0 0 4}$ & $\mathbf{2 0 0 6}$ & $\mathbf{2 0 0 8}$ & $\mathbf{2 0 1 0}$ & $\mathbf{2 0 1 2}$ & $\mathbf{2 0 1 4}$ & $\mathbf{2 0 1 6}$ & $\mathbf{2 0 1 8}$ & $\mathbf{2 0 2 0}$ & $\mathbf{2 0 0 0 - 2 0 2 0}$ \\
\hline India & 21 & 0 & 28 & 33 & 15 & 5 & 0 & 36 & 46 & 44 & 151 & 588 \\
\hline SA & - & - & - & 18 & - & 1 & 62 & 3 & 5 & - & - & 89 \\
\hline UAE & - & - & 3 & 17 & - & 39 & 69 & 77 & 102 & 121 & 191 & 1147 \\
\hline
\end{tabular}

Source: compiled by the authors according to the SIPRI Yearbook 2020

Exports from India, although small in volume, are growing rapidly. SA is only at the beginning of the path; its volumes are very small. The UAE has dramatically increased the export of weapons and military equipment over the past 10 years. The importers of Indian weapons are the countries of the nearest region with a low level of income. SA is just embarking on the path of its own military production, therefore, its exports are very limited to a narrow circle of consumers. The UAE sells its weapons mainly to Arab countries. As for the types of weapons and military equipment, these are mainly aircraft and armored vehicles and warships.

Japan has a special situation. The country is strong in high-tech manufacturing. Due to the pacifist constitution of Japan, the country did not enter the world arms markets throughout the second half of the twentieth century, although it produced them for its own self-defense forces. Japan's military expenditures, a significant part of which goes to the production of products for the self-defense forces, have been stable over the past decades and are comparable in magnitude with the military expenditures of the largest exporters of the market, such as France, Germany and Russia (see Table 12).

Table 12. Military expenditures of Japan, France, Germany and Russia for 2000-2020 (\$ million)

\begin{tabular}{|l|c|c|c|c|c|}
\hline & $\mathbf{2 0 0 0}$ & $\mathbf{2 0 0 5}$ & $\mathbf{2 0 1 0}$ & $\mathbf{2 0 1 5}$ & $\mathbf{2 0 2 0}$ \\
\hline Japan & 46223 & 47052 & 46420 & 47600 & 48160 \\
\hline Germany & 42403 & 33323 & 41046 & 40566 & 51570 \\
\hline France & 45010 & 47469 & 48415 & 48033 & 51572 \\
\hline Russia & 23584 & 35165 & 49834 & 74649 & 66838 \\
\hline
\end{tabular}

Source: compiled by the authors according to the SIPRI Yearbook 2020

Japan's potential as an exporter of WME is enormous. The appearance of some Japanese military corporations in the tops of the largest military companies speaks of rapidly growing production, some of which may and is already being exported. For example, in the TOP-100 SIPRI 2018, Mitsubishi Heavy Industries is in 25th place with $\$ 3.7$ billion in military sales (to the self-defense forces). In addition to it, the TOP-100 includes 4 more Japanese companies. In recent years, exports from Japan went mainly to the United States and amounted to $\$ 40$ million out of the total for the period of $\$ 46$ million (another $\$ 6$ million were exported to the Philippines) and this is only Aircraft. Imports of weapons and military equipment to Japan for the period 2000-2020 amounted to \$9787 million. The country purchased the bulk of WME from the United States - \$9042 million.

In the near future, Japan's position as an exporter of weapons and military equipment may strengthen, since in recent years the country's leadership has sought to change some provisions of the Constitution prohibiting the sale of weapons.

\section{Conclusions}

The USA, Russian Federation, France and Germany continue to hold leading positions in the AME markets as the main exporters. They manufacture a full range of weapons. The circle of importers of Russian weapons differs from the partners of other leading players, but in recent years there has been a process of penetration of competitors into the traditionally 


\begin{abstract}
"Russian" arms markets. As for the dynamics of arms export deliveries, out of the top four, only the United States has a steady upward trend in volumes. France, Germany and, to a lesser extent, Russia show significant fluctuations in supply volumes from year to year. Obviously, the larger the backlog of orders a country has, the less fluctuations in export volumes will be over the years.

The aggravation of competition among exporters of weapons and military equipment is facilitated by the emergence of new "players" on the market, who significantly increased their export of weapons and military equipment during the period under review. First of all, we are talking about China. In the coming years, this trend will continue due to the strengthening of South Korea's positions and an increase in the volume of arms and military equipment exports from the UAE, SA and India. In this group of those "catching up", only China in serious volumes produces almost the entire possible range of weapons and military equipment. The rest are basically "specializing" in one or two types of weapons. Exports of high-tech weapons from Japan could be potentially very large.
\end{abstract}

\title{
References
}

1. Akbas-Yesilyurt. F., Yesilyurt, M.E. (2020) Non-standard Sources for Arms Production and Arms Trade Data. Ege Academic Review, 20(2), 91-99.

2. Bitzinger, R. (2016). Reforming China's defense industry. Journal Of Strategic Studies, 39(5-6), 762-789.

3. Blum, J. (2019). Arms production, national defense spending and arms trade: Examining supply and demand. European Journal of Political Economy, 60, 101814.

4. CAWAT 2016 (2021, July 11). Analytic note. Commentary on the next SIPRI annual report. CAWAT. https://armstrade.org/files/analytics/342.pdf

5. Comparison of Russia and United States Military Strengths (2021) (2021, July 11). Global Firepower - World Military Strength. https://www.globalfirepower.com/countriescomparison-detail.php?form $=$ form $\&$ country $1=$ russia\&country $2=$ united-states-ofameric a \&Submit=COMPARE

6. Dengov, V., Tulyakova, I., \& Gregova, E. (2018). Military-Technical Cooperation of Russia in the Context of Globalization: Experience of Cooperation with China. Globalization and its Socio-Economic Consequences, 10, 78.

7. Dengov, V., Tulyakova, I., \& Gregova, E. (2021). Positions and prospects of Russian shipbuilding in the world market of naval equipment. In SHS Web of Conferences (Vol. 92). EDP Sciences.

8. Fleurant, A., \& Tian, N. (2018). SIPRI's arms producing and military services companies database. Economics of Peace and Security Journal, 13 (2), 5-10.

9. Gregova, E., Tulyakova, I., \& Dengov, V. (2021, January). Actual problems and limiting factors in the development of the Russian military-industrial complex. In SHS Web of Conferences (Vol. 92, p. 07021). EDP Sciences.

10. Liu, SQ., Li, YF., \& Xiao, XY. (2014). Comparative Analysis on Data Sources of Arms Trade. In Q. Zhou (Ed.) International Conference on Business, Economics and Management (BEM 2014): Vol. 1, 59-63.

11. McGann, J.G. (2021, July 9). 2019 Global Go To Think Tank Index Report, section «Top Defense and National Security». https://repository.upenn.edu/cgi/viewcontent. cgi? article $=1018 \&$ context $=$ think tanks

12. SIPRI Yearbook 2021(2021, July 9). SIPRI. https://www.sipri.org/yearbook/2021 
13. Skons E., Dunne J.P (2008). Arms Production, Economics Of. Ch. In: Encyclopedia of Violence, Peace, and Conflict. (1st ed.). In L. Kurtz (Ed.). Academic Press.

14. Tulyakova, I. R. (2016). The United States and Russia on the global arms markets. In Globalization and its Socio-Economic Consequences (pp. 2236-2244).

15. Tulyakova, I. R., \& Dengov, V. V. (2018). Military-Technical Cooperation of Russia in the Context of Globalization: Experience of Cooperation with India. In Globalization and its Socio-Economic Consequences (pp. 1401-1408).

16. Tulyakova, I. R., Dengov, V. V., \& Gregova, E. (2019). The positions of Russia and Croatia shipbuilding products on world markets and prospects of co-operation (analytical overview). NAŠE MORE: znanstveni časopis za more i pomorstvo, 66(3 Supplement), 13-21.

17. Tulyakova, I. R., Gregova, E., \& Dengov, V. V. (2017). Assessment of Competitiveness of Shipbuilding Industry in Russia. NAŠE MORE: znanstveni časopis za more $i$ pomorstvo, 64(3), 112-119.

18. Wang, K-H., Su, C-W., Tao, R., \& Chang, H.L. (2019). Does the Efficient Market Hypothesis Fit Military Enterprises in China? Defence and Peace Economics, 30(7), 877-889. 